\title{
Modelling the influence of gaseous products of explosive detonation on the processes of crack treatment while rock blasting
}

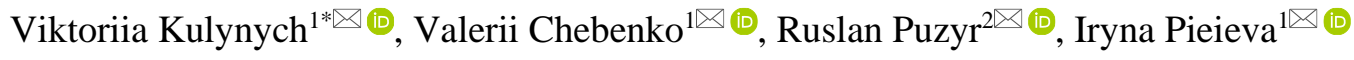 \\ ${ }^{1}$ Kremenchuk Mykhailo Ostrohradskyi National University, Kremenchuk, 39600, Ukraine \\ ${ }^{2}$ Kremenchuk Mykhailo Ostrohradskyi National University College, Kremenchuk, 39621, Ukraine \\ *Corresponding author: e-mail vikulsija@gmail.com, tel.+380663018516
}

\begin{abstract}
Purpose is mathematical modeling of fracturing as well as influence of gaseous products of explosive detonation on the changes in rock strength.

Methods. Mathematical model, using foundations of Griffith theory, has been developed. To explain conditions of bridge formation while exploding lead azide charges, a two-stage description of solid particle condensation at a crack surface and inside it has been applied using the smoothed particle hydrodynamics. The analysis, involved electronic microscope, has helped verified the results experimentally.

Findings. The effect of rock mass disturbance, resulting from explosive destruction, is manifested maximally right after the action. Subsequently, it decreases owing to the gradual relaxation of the formed defects. Therefore, an urgent problem is to develop ways slowing down strength restore of the blasted rock mass fragments. The process of rock fragment strength restoring may be prevented by microparticles getting into the microcrack cavities together with the detonation products. The research simulates their action. The data correlate to the simulation results confirming potential influence of the blasted rock on the dynamics of changes in the strength characteristics of the rock mass. Various compositions of charges with shells made of inert solid additions have been applied which solid particles can avoid the process of microcrack closure.
\end{abstract}

Originality. For the first time, the possibility of deposition formation within rock micro- and macrocracks has been proposed and supported mathematically.

Practical implications. Strength properties of the finished product and the energy consumption during impulse loading as well as subsequent mechanical processing of nonmetallic building materials depend on the strength properties of rock mass fragments. Hence, the ability to control the strength restore has a great practical value. Moreover, it can be implemented during the blasting operations.

Keywords: deposits, disturbance, labradorite, lead azide, dust, sublimation, smoothed particle hydrodynamics method, microcracks, macrocracks, Griffith theory

\section{Introduction}

The majority of engineering and building materials are of heterogeneous structure; they contain many defects of crystal lattice, microcracks, and foreign inclusions with different physicomechanical and physicochemical properties. Currently, considerable attention is paid to theoretical and experimental studies of their fracture mechanism [1]-[3].

Mostly, mineral raw materials, represented by rocks, are mined by means of commercial blasting. Blasting power is characterized by a stress wave within the rock mass, neighbouring the charge, as well as by gas-dynamic processes in detonation products within the cavities of micro- and macrocracks they get in. Influence of the factors varies parame- ters of the microcracks; moreover, density of defects in the crystal lattices of minerals and rocks increases.

It has been identified that destruction process of various materials (even if they are relatively homogeneous) results in crack formation under the effect of external loads. The process is followed by origination of arches, connections, dividers, and other formations generally called "bridges" [1], [2]. In the context of rocks, both origination and subsequent evolution of artificial bridges in the process of blasting are associated with the characteristic parameters of impulse action making it possible to simulate formation of the bridges, determine mathematical, physicomechanical, and physicoche-mical mechanisms of the process. 
Lately, a tendency has been appeared to use the results of studies of energy intensity level of various rock mass zones to substantiate rational parameters as for the location of both main and additional charges while huge blast scheduling in open pits. Papers [1], [4], [5] analyze disturbance processes as well as processes of destructive explosion action in solid media; residual rock strength in terms of non-destructive explosive and mechanical impacts; and intensity and uniformity of models and rock mass fragmentation depending on location parameters of additional and main charges. Authors describe blasting results as for the samples and rock masses with block and layered structure; and stress-strain state of the layered and cracked media in the blast [5], [6]. Residual strength of samples, subjected to non-destructive impulse influences, is determined experimentally making it possible to estimate the coefficient of the explosion energy transfer into a rock mass without fundamental difficulties. Estimation of a transfer coefficient of the total charge energy shows that the power consumption for the collision of individual parts of the block rock models cannot exceed $0.5 \%$; in turn, the stress wave energy losses may achieve up to $50 \%$ even in terms of transition through the tightly closed cracks.

Compared to mechanical fragmentation and grinding, explosive fracture is characterized by much more energy share consumed to disturb the rock [1]. Explosive fracture occurs owing to the development of long cracks under the action of tensile stresses and wedging action of blasting fumes. Cracks are not accidental. Usually, they result from macrodefects in the rock structure. In addition, during explosive action, cracks originate. They do not propagate in future instead affecting the strength of the resulting raw material.

Thus, the solid medium destruction by an explosion prior to separation into parts [6] includes accumulation, development, and closure of different size cracks. Initial stage of the process is associated with an increase in the microcracks concentration largely determined by physicomechanical properties. Consequently, control of the parameters will improve efficiency of the explosive rupture.

It is known [7], [8] that explosion impact by industrial explosives is characterized by two parameters - stress intensity at the front of the disturbance wave and pressure of the gaseous detonation products within the charging chamber and the microcrack cavities.

Penetration of the gaseous detonation products into micro- and macrocracks contributes to rock destruction owing to the wedging effect affecting changes in the strength of the fragments formed during the explosion. For a time, the gaseous detonation products are retained within the cavities of cracks at the surfaces of their walls at the expense of adsorption. Certain gas share trapping complicates their collapse. As the pressure in the charging chamber decreases, potential collapse of certain microcracks increases due to the tensile stresses by bridges [4].

It is possible to decelerate the recovery of the rock strength or avoid it while introducing finely dispersed inert solid particles into the explosive charge, which, together with the detonation products, can penetrate into the microcracks cavities and, settling on the walls, prevent them from closing.

Artificial bridges within microcrack cavities may result from the ingression of detonation products containing the substances sublimating during the explosion; then, temperature decrease makes them condense on their walls in the form of deposits (for example, iodine). Tensile stresses are either nonavailable within artificial bridges or values of the stresses are minor.

Solid adsorption layers (deposits) may originate at the surfaces of the microcrack cavities; thickness of the layers is one or several molecules. Within certain section, thickness of the deposits may exceed the microcrack width, stipulating its widening and, hence, strength reduction of rock fragments after blasting is over.

In terms of impulse loading and subsequent mechanical processing of nonmetallic building materials, strength properties of the finished product as well energy consumption depend upon strength properties of rock fragments. At the same time, rock mass processing at rock-crushing plants has an ambiguous effect on the crushed stone strength. On the one hand, reduction in the fragment sizes improves their strength at the expense of the scale factor; on the other hand, in terms of impulse mechanical actions, the abovementioned microcracking nature reduces it. Numerous experiments have been carried out to support the proposed hypothesis; however, no unified mathematical model describing the mechanisms has been developed.

Therefore, the cracking process modelling and influence of gaseous detonation products (DPs) of explosives (Es) on the changes in nonmetallic rock strength characteristics is of scientific and practical interest being the research purpose.

Based on the foregoing, the main problems of the study are:

- analysis of modern scientific research in the field of fracture closure and disturbance processes during the hard rock extraction;

- substantiation of deposit (bridge) formation within micro- and macrocracks during the hard rock fragmentation developed to prevent their closure;

- confirmation of the proposed hypothesis while modeling and making experiments.

\section{Methods}

The initial stage of the research involved the development of a mathematical model based upon Griffith theory foundations. The theory describes crack behaviour as well as forces arising in it.

To explain the conditions of deposit formation during the model blasting by means of lead azide charges, a description of condensation mechanism of solid particles at the surface of crack and inside them was applied using a two-stage approach of the smoothed particle hydrodynamics (SPH) [9]-[11].

Stage one of the experiment simulated lead azide (LA) molecularly using $\left(7 \cdot 10^{-4} \mathrm{~m}\right)$ particles. The following was assumed while selecting the theoretical model [12], [13]:

1) lead azide purity is $96 \%$;

2) the charge is of spherical shape; initiation takes place in the central share of the sphere; and a massless (noninertial) single particle acts as an initiator;

3) detonation is followed by the reactions:

$$
\begin{gathered}
\mathrm{Pb}\left(\mathrm{N}_{3}\right)_{2} \rightarrow \mathrm{Pb}+\mathrm{N}_{3} \\
\mathrm{~N}_{3} \rightarrow \mathrm{N}_{2}+\mathrm{N} \\
\mathrm{N}_{3}+\mathrm{N} \rightarrow \mathrm{N}_{2}+\mathrm{N}_{2}{ }^{*}
\end{gathered}
$$

(asterisk denotes electronic excited triplets);

4. at collision, $\mathrm{N}_{2}{ }^{*}$ transfer energy to metal atoms (probability is $67 \%$ );

5) detonation products expand within inert gas with atomic mass 29, and $101 \mathrm{kPa}$ pressure.

Stage two of the experiment involved macroscopic simulation. Following crack geometry was selected as the initial 
parameters: $0.3 \mathrm{~mm}$ length (Y-axis); $0.6 \mathrm{~mm}$ height (Z-axis); and $2 \cdot 10^{-6} \mathrm{~m}$ mouth (X-axis).

It should be mentioned that while blasting, artificial bridges may be developed in a number of different ways:

1) getting into microcracks with gaseous detonation products and mechanical movement of fine inert solid particles within them;

2) delivery of an inert gaseous substance by detonation products with its subsequent condensation on the cold walls of microcrack cavities;

3) filling the cavities of microcracks with solid particles while using explosives, which detonation products contain components prone to coagulation (fusion) and adsorption in terms of temperature as well as pressure drop.

For experimental confirmation of the above, the first method was selected. Construction cement in the form of an outer shell of explosive charge was used as a finely dispersed inert additive for the series of experiments [14], [15]. Labradorite samples were used. When a non-destructive explosive charge containing fine dust as a shell was blasted, the model was divided into parts using a metal wedge; the fracture surfaces were analyzed with the help of an electron microscope.

\section{Results and discussion}

\subsection{Theoretical substantiation of the gaseous detonation products behaviour in a crack}

Since rock disturbance results from microfissuring, use Griffith theory to analyze some aspects of the phenomenon [16]. According to the theory, brittle materials contain randomly oriented microcracks, within which tips (or near them) stresses concentrate (Fig. 1); hence, crack propagation takes place and, ultimately, macroscopic fracture. For a unit thickness layer, the maximum stress $\sigma_{\max }$ at an elliptical crack tip depends on the curvature radius $\rho$ within the tip and the crack length $2 \mathrm{c}$ :

$\sigma_{\max }=2 \sigma_{0}\left(\frac{c}{\rho}\right)^{\frac{1}{2}}$

where:

$\sigma_{0}-$ an average stress within the sample.

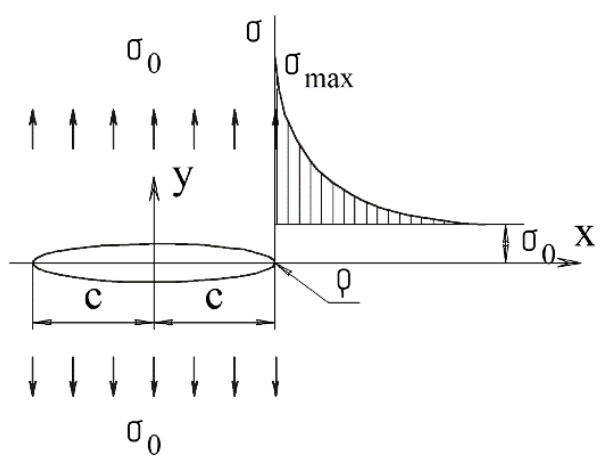

Figure 1. Stress distribution at the tip of an elliptical crack

The difference between the energy values of a unit thickness layer and constant length with an elliptical crack and without it is:

$U_{e}=\frac{\pi c^{2} \sigma_{0}^{2}}{E}$, where:

$E$ - longitudinal elastic modulus of the material.

Surface energy during crack formation is:

$U_{s}=4 c T$,

where:

$T$ - surface tension.

Consequently, an elliptical crack reduces the total energy $U$ :

$U=U_{e}-U_{s}=\frac{\pi c^{2} \sigma_{0}^{2}}{E}-4 c T$.

Following condition determines both unstable state and the beginning of a crack development:

$\frac{\partial U}{\partial c}=0 ; \sigma_{0}^{2}=\frac{2 E T}{\pi c}=\sigma_{p}^{2}$

where:

$\sigma_{p}$ - tensile strength of the material.

Hence, a crack propagation process starts when $\sigma_{0}$ stresses, applied to the sample (Fig. 1), achieve the ultimate tensile strength of the material.

During the explosive impact, rocks are mainly subjected to compressive loads. Based on Griffith theory, consider the conditions for a microcrack growth and rock sample disturbance under uniaxial compression. It should be taken into account that Griffith model of an elliptical crack roughly represents actual tightly closed microcracks in rocks. Therefore, use a model of a perfectly thin closed crack which can be considered as a limiting case of an elliptic one when $\rho \rightarrow 0$. Then, in accordance with the Formula (1), the maximum stresses are $\sigma_{\max } \rightarrow \infty$; however, their values are limited due to the material transition into a plastic state.

Plastic deformations occur within the crack tip as well as within the adjacent region, which dimensions are determined by $r_{1}\left(0 r_{1}<r\right)$ distance; consequently, the considered dependences are valid in the range of $r r_{1}$ values.

Select a thin layer with an arbitrarily oriented crack in a sample subjected to uniaxial compression (Fig. 2). Normal $\sigma_{\phi}$ stress and shear $\tau_{\phi}$ stress will act on the crack surface.

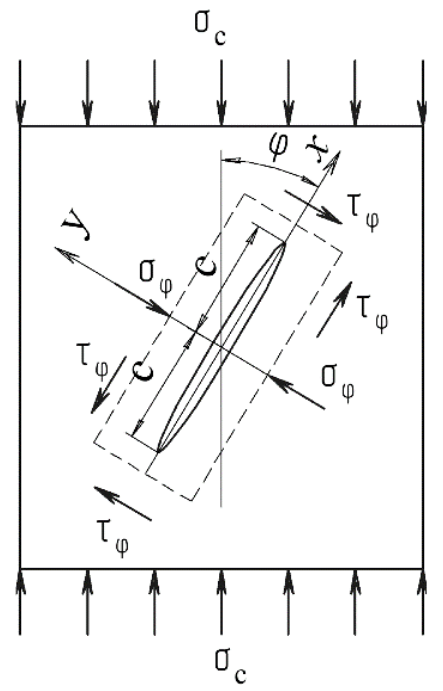

Figure 2. Stress state near a thin crack within a compressive stress field ( $\sigma_{c}$ are normal compressive stresses) 
Normal compressive stresses do not affect the stress distribution near an ideally thin closed crack; therefore, it can be assumed that only shear stresses are applied to the crack surface, i.e. the stressed state is characterized by pure shear.

In this case, the stress components near the crack tip are:

$\sigma_{x}=\tau_{\phi}\left(\frac{c}{2 r}\right)^{\frac{1}{2}} \sin \frac{\theta}{2}\left(2+\cos \frac{\theta}{2} \cdot \cos \frac{3 \theta}{2}\right)$

$\sigma_{y}=\tau_{\phi}\left(\frac{c}{2 r}\right)^{\frac{1}{2}} \sin \frac{\theta}{2} \cdot \cos \frac{\theta}{2} \cdot \cos \frac{3 \theta}{2} ;$

$\tau_{x y}=\tau_{\phi}\left(\frac{c}{2 r}\right)^{\frac{1}{2}} \cos \frac{\theta}{2}\left(1-\sin \frac{\theta}{2} \cdot \sin \frac{3 \theta}{2}\right)$,

where:

$r$-distance from the crack tip to the point under consideration (Fig. 3).

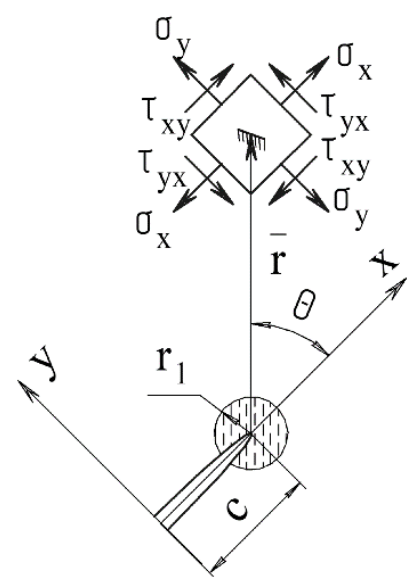

Figure 3. Stress components in front of the tip of a thin crack $\left(r_{1}\right.$ is the radius of plastic deformations)

Crack propagation potential depends on its orientation. The development of cracks, at which maximum stresses $\tau_{\phi}$ occur, is the most probable idea since in terms of pure shear:

$\tau_{\phi}=\frac{\sigma_{c}}{2} \cdot \sin 2 \phi$

then $\tau_{\phi}=\tau_{\max }=\sigma_{c} / 2$ when $\phi=45^{\circ}$.

The stress state analysis of the material near the crack tip has showed that under otherwise equal conditions, strength degradation of rock samples during compression is most likely due to the microcrack development oriented at an angle of $45^{\circ}$ toward the compressive load. The abovementioned helps assume that strength degradation of the samples should manifest itself not only in the operative direction of the impulse non-destructive load but also perpendicularly to it.

Growth of the macrocracks and their formation can be represented as a continuous process of their initiation creation and coalescence ahead of the fracture front edge. Taking into consideration the high degree of rock heterogeneity, there is a high probability of a developing microcrack entering an area with higher strength characteristics. Within the area, no rock discontinuity takes place; stress state is developed; and the crack development discontinues. Right the undisturbed areas form bridges drawing together crack edges behind the fracture front.

\subsection{Experimental study of a crack treatment process}

Stage one of the simulations has helped understand the following:

1. In terms of percentage by weight, detonation product cloud contains:

a) $4.0 \%$ of impurities, i.e. inert particles;

b) $6.7 \%$ of undetonated LA fractures. Since particle size is first determined by a model (type) of the initiating charge, the mentioned particles cannot be used for further conclusions and interpretations at macroscopic level;

c) $27.7 \%$ of $\mathrm{N}, \mathrm{N}_{2}, \mathrm{~N}_{2}{ }^{*}$, and $\mathrm{N}_{3}$;

d) $41.7 \%$ of lead particles (average characteristic size of a lead particle is $1.7 \cdot 10^{-6} \mathrm{~m}$;

e) $19.9 \%$ of lead atoms

2. According to the calculation, at a $2.55 \mathrm{~mm}$ distance, average velocities of detonation products are:

a) $2.9 \cdot 10^{3} \mathrm{~m} / \mathrm{s}$ by solid particles;

b) $1.8 \cdot 10^{3} \mathrm{~m} / \mathrm{s}$ by gaseous products.

The stage findings have been used to model a mechanism of detonation product entering the microcracks at a solid wall surface. The experiment has demonstrated that the model walls experience both elastic and elastoplastic deformations as well as brittle failure.

Findings of stage two of the calculations are as follows:

1. The microcrack geometry is:

a) length is $0.324 \mathrm{~mm}$;

b) height is $0.817 \mathrm{~mm}$;

c) mouth is $2,16 \cdot 10^{-6} \mathrm{~m}$.

2. Lead particles with $\left[1 \cdot 10^{-7} \ldots 1 \cdot 10^{-6} \mathrm{~m}\right]$ diameters $(\sim 0.03 \times \ldots 0.1 \times$ of a micro-crack opening). First, in the neighborhood of crack mouths, some particles move along the surfaces of their walls approaching the tips. The fact can be explained by "pushing" at the expense of particles joined them later. The abovementioned particles produce larger formations.

In terms of $60 \%$ of cases, the process results in the formation of rather large particles able to be bridges through microcracks preventing from their collapse while widening them.

The photographs, obtained with an electron microscope, demonstrate microcracks cavities filled with cement particles. Surface of the sample split surface, assumed as a model, (Fig. 4a), has an empty characteristic crack. Maybe, it will close up with time under the influence of external forces. At the same time, Figure $4 \mathrm{~b}$ shows cavities of microcracks filled with cement particles. Hence, getting into microcracks during explosion, cement dust almost completely fills their cavities, preventing subsequent collapse and rock strength restoration, which is confirmed by the simulation results.

Despite the positive results of the research, the proposed method should be tested under the field conditions to assess its effectiveness, taking into account the scale factor.

\section{Conclusions}

The effect of rock mass disturbance is manifested maximally right after explosive destruction; subsequently, it decreases with time due to gradual relaxation of the formed defects. Therefore, an urgent task is to develop the ways to slow down the process of restoring the blasted rock mass pieces. The process, restoring rock mass strength, may be prevented by microparticles getting into cavities of the microcracks with detonation products. 
(a)

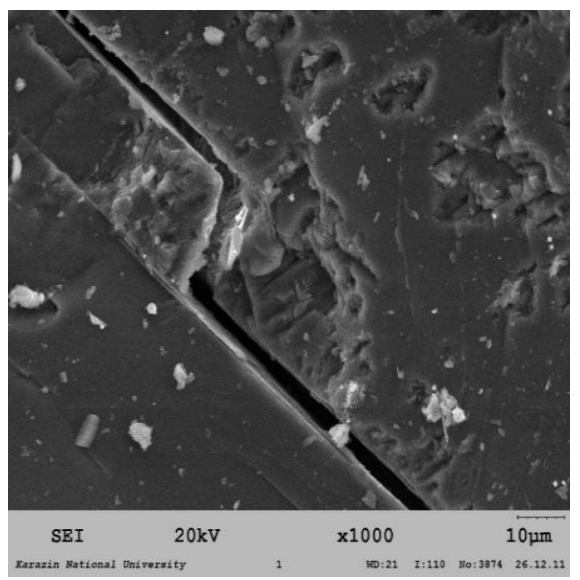

(b)

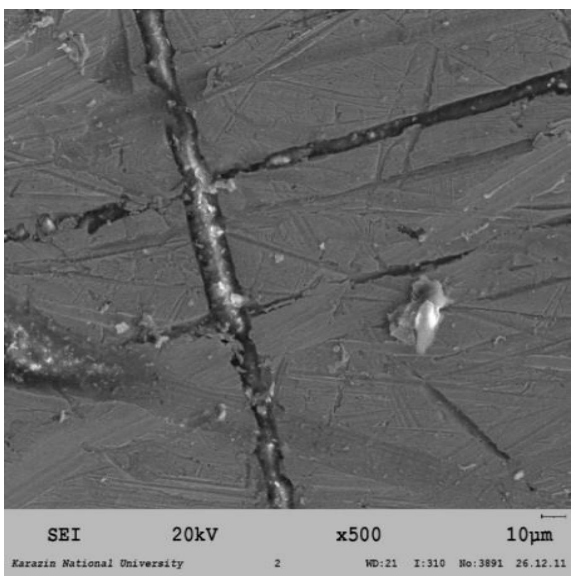

Figure 4. The nature of the microcracks cavity filling with solid inert particles during the explosion of explosive charges: (a) free microcracks of the model after the explosion of a uniform charge; (b) cavities of microcracks filled with inert particles after the explosion of charges, having a shell of fine dust

A process of the formation of deposit (i.e. bridges) within micro- and macrocracks of rocks has been simulated using fracture theory with the smoothed particle hydrodynamics (SPH) method in terms of lead azide.

The obtained data correlate with the simulation results confirming the possibility of influencing the change dynamics in the rock mass strength characteristics obtained by the explosion using various charges compositions with shells from inert solid additives, which solid particles can interfere with the process of microcrack closing.

\section{Acknowledgements}

The authors are grateful to V.M. Komir whose ideas were taken as the basis.

\section{References}

[1] Komir, V., \& Nazarenko, V. (1978). The role of gaseous detonation products in the process of destruction of a solid medium. Explosion Case, 80(37), 77-80.

[2] Kuk, M.A. (1980). The science of industrial explosives (pp. 402-407). New York, United States.

[3] Komir, V., Klochko, I., Doludareva, Ya., \& Pejeva, I. (2011). The nature of changes in the strength properties of rocks as a result of exposure to explosion of explosive charges. Suchasni Resursoenerhozberihauchi Tehnolohii Hirnychoho Vyrobnytstva, 1(7), 16-21.

[4] Komir, V., Doludarev, V., Doludareva, Ya., Kozlovskaya, T., Komir, A., \& Lemizhanskaya, V. (2011) Behavioral features of solid rocks at impulsive impact of industrial explosives charges. Transactions of Kremenchuk Mykhailo Ostrohradskyi National University, 6(71), 123-127.

[5] Doludareva, Ya., Lemizhanska, V., Kozlovska, T., \& Komir, A. (2012). The influence of surface-active substances in the region of rock destruction on the intensity of their fragmentation under the action of pulsed loads. Naukovyi Visnyk Natsionalnoho Hirnychoho Universytetu, (130), 93-97.

[6] Vorobyov, V., Pomazan, M., Shlyk, S., \& Vorobyova, L. (2017). Simulation of dynamic fracture of the borehole bottom taking into consideration stress concentrator. Eastern-European Journal of Enterprise Technologies, 3(1(87)), 53-62. https://doi.org/10.15587/17294061.2017.101444

[7] Heim, A.J., Grønbech-Jensen, N., Kober, E.M., Erpenbeck, J.J., \& Germann, T.C. (2008). Interaction potential for atomic simulations of conventional high explosives. Physical Review E, 78(4), 046709. https://doi.org/10.1103/physreve.78.046709

[8] Heflinger, D., Bar, I., Ben-Porat, T., Erez, G., \& Rosenwaks, S. (1993). Dynamics of the detonation products of lead azide. II. Formation of charged particles. Journal of Applied Physics, (73), 2138. https://doi.org/10.1063/1.353140

[9] Salenko, Y., Puzyr, R., Shevchenko, O., Kulynych, V., \& Pedun, O. (2020). Numerical simulation of local plastic deformations of a cylindrical workpiece of a steel wheel rim. Lecture Notes in Mechanical Engineering, 442-451. https://doi.org/10.1007/978-3-030-50794-7 43

[10] Gorbatyuk, S.M., Shapoval, A.A., Mos'pan, D.V., \& Dragobetskii, V.V. (2016). Production of periodic bars by vibrational drawing. Steel in Translation, 46(7), 474-478. https://doi.org/10.3103/s096709121607007x

[11] Markov, O.E., Gerasimenko, O.V., Shapoval, A.A., Abdulov, O.R., \& Zhytnikov, R.U. (2019). Computerized simulation of shortened ingots with a controlled crystallization for manufacturing of high-quality forgings. The International Journal of Advanced Manufacturing Technology, 103(5-8), 3057-3065. https://doi.org/10.1007/s00170-019-03749-4

[12] Zhou, M., Liu, S., Du, M., Shi, X., Zhao, Z., Guo, L., \& Liu, B. (2020). High-pressure-induced structural and chemical transformations in $\mathrm{NaN}_{3}$. The Journal of Physical Chemistry C, 124(37), 19904-19910. https://doi.org/10.1021/acs.jpcc.0c04107

[13] Schneider, S., Hawkins, T., Rosander, M., Mills, J., Brand, A., Hudgens, L., \& Vij, A. (2008). Liquid azide salts. Inorganic Chemistry, 47(9), 3617-3624. https://doi.org/10.1021/ic702068r

[14] Maslov, A., Batsaikhan, J., Puzyr, R., \& Salenko, Y. (2018). The determination of the parameters of a vibration machine in the internal compaction of concrete mixtures. International Journal of Engineering \& Technology, 7(4,3), 12-19. https://doi.org/10.14419/ijet.v7i4.3.19545

[15] Kholodenko, T., Ustimenko, Y., Pidkamenna, L., \& Pavlychenko, A. (2015). Technical, economic and environmental aspects of the use of emulsion explosives by ERA brand in underground and surface mining. New Developments in Mining Engineering 2015, 211-219. https://doi.org/10.1201/b19901-38

[16] Ván, P., Papenfuss, C., \& Muschik, W. (2004). Griffith cracks in the mesoscopic microcrack theory. Journal of Physics A: Mathematical and General, 37(20), 5315-5328. https://doi.org/10.1088/03054470/37/20/005

\section{Моделювання впливу газоподібних продуктів детонації вибухових речовин на процеси заліковування тріщин при вибуховій відбійці скельних гірських порід}

\section{В. Кулинич, В. Чебенко, Р. Пузир, І. Пєєва}

Мета. Моделювання процесу утворення тріщин і впливу на нього газоподібних продуктів детонації вибухових речовин на зміну міцності нерудних гірських порід.

Методика. Побудовано математичну модель із використанням основ теорії Гріффітса. Аналіз механізму конденсації твердих частинок на поверхні та всередині тріщини (для пояснення умов утворення мостів під час вибуху зарядів азида свинцю) проведено 
за допомогою двоетапного підходу із використанням гідродинаміки згладжених частинок. Для експериментального підтвердження отриманих результатів проведено експериментальні дослідження із використанням електронного мікроскопа.

Результати. Ефект знеміцнення гірської маси після вибухового руйнування в максимальному ступені проявляється відразу $\mathrm{i}$ надалі з часом знижується внаслідок поступової релаксації утворених дефектів, тому актуальним завданням $\epsilon$ розробка способів уповільнення процесу відновлення міцності шматків відбитої вибухом гірської маси. Процесу відновлення міцності можуть перешкоджати мікрочастинки, що потрапляють всередину порожнин мікротріщин з продуктами детонації, моделювання дії яких описано в роботі. Отримані експериментальні дані корелюють з наведеними результатами моделювання і підтверджують можливість впливу на динаміку зміни характеристик міцності одержуваної вибухом гірської маси, використовуючи різні склади зарядів 3 оболонками з інертних твердих добавок, тверді частинки яких можуть перешкодити процесу змикання мікротріщин.

Наукова новизна. Вперше запропоновано та математично підтверджено можливість утворення відкладень (депозитів) у мікроі макротріщини гірських порід.

Практична значимість. Міцність готового виробу та енерговитрати при імпульсному навантаженні й подальшій механічній обробці неметалічних будівельних матеріалів залежать від фізико-механічних властивостей шматків гірської маси, тому здатність керувати відновленням міцності має велике практичне значення і може впроваджуватися при проведенні вибухових робіт.

Ключові слова: депозити, знеміцнення, лабрадорит, азид свинцюю, пил, сублімація, метод гідродинаміки згладжених частинок, мікротріщини, макротріщчини, теорія Гріффітса

\section{Моделирование влияния газообразных продуктов детонации взрывчатых веществ на процессы залечивания трещин при взрывной отбойке скальных горных пород}

\section{В. Кулинич, В. Чебенко, Р. Пузырь, И. Пеева}

Цель. Моделирование процесса трещинообразования и влияния на него газообразных продуктов детонации взрывчатых веществ на изменение прочностных характеристик нерудных горных пород.

Методика. Построена математическая модель с использованием основ теории Гриффитса. Для объяснения условий образования мостов при взрыве зарядов азида свинца было использовано описание механизма конденсации твердых частиц на поверхности и внутри трещины двухэтапным подходом с использованием гидродинамики сглаженных частиц. Для экспериментального подтверждения полученных результатов использовались исследования с помощью электронного микроскопа.

Результаты. Эффект разупрочнения горной массы после взрывного разрушения в максимальной степени проявляется сразу и в дальнейшем со временем снижается вследствие постепенной релаксации образовавшихся дефектов, поэтому актуальной задачей является разработка способов замедления процесса восстановления прочности кусков отбитой взрывом горной массы. Процессу восстановления прочности кусков горной массы могут препятствовать микрочастицы, попадающие внутрь полостей микротрещин с продуктами детонации, моделирование действия которых описано в работе. Полученные данные коррелируют с приведенными результатами моделирования и подтверждают возможность влияния на динамику изменения прочностных характеристик получаемой взрывом горной массы, используя различные составы зарядов с оболочками из инертных твердых добавок, твердые частицы которых могут помешать процессу смыкания микротрещин.

Научная новизна. Впервые предположена и математически подтверждена возможность образования отложений (депозитов) в микро- и макротрещинах горных пород.

Практическая значимость. Прочностные свойства готового изделия и энергозатраты при импульсном нагружении и последующей механической обработке неметаллических строительных материалов зависят от прочностных свойств кусков горной массы, поэтому способность управлять восстановлением прочностных характеристик имеет большое практическое значение и может внедряться при проведении взрывных работ.

Ключевые слова: отложения, разупрочнение, лабрадорит, азид свиниа, пыль, сублимация, метод гидродинамики сглаженных частиц, микротрещины, макротрещиины, теория Гриффитса 